\title{
Speech Acts in the Facebook Status Updates Posted by an Apostate
}

\author{
Azweed Mohamad ${ }^{1}$, Radzuwan Ab Rashid ${ }^{1}$, Kamariah Yunus ${ }^{1}$, Shireena Basree Abdul Rahman ${ }^{2}$, Saadiyah \\ Darus $^{3}$, Razali Musa ${ }^{4} \&$ Kamarul Shukri Mat Teh ${ }^{4}$ \\ ${ }^{1}$ Faculty of Languages and Communication, Universiti Sultan Zainal Abidin, Kuala Nerus, Terengganu, \\ Malaysia \\ ${ }^{2}$ Faculty of Education, Universiti Teknologi Mara, Puncak Alam, Selangor, Malaysia \\ ${ }^{3}$ Faculty of Social Sciences and Humanities, Universiti Kebangsaan Malaysia, Bangi, Selangor, Malaysia \\ ${ }^{4}$ Faculty of Contemporary Islamic Studies, Universiti Sultan Zainal Abidin, Kuala Nerus, Terengganu, Malaysia \\ Correspondence: Radzuwan Ab Rashid, Faculty of Languages and Communication, Universiti Sultan Zainal \\ Abidin, Kuala Nerus, Terengganu, Malaysia. E-mail: radzuwanrashid@unisza.edu.my
}

Received: February 2, 2018 Accepted: April 19, 2018 Online Published: April 24, 2018

doi:10.5539/ijel.v8n4p226 URL: https://doi.org/10.5539/ijel.v8n4p226

\begin{abstract}
This paper discusses the speech acts in Facebook Status Updates posted by an apostate of Islam. The Facebook Timeline was observed for a duration of two years (January 2015 to December 2016). More than 4000 postings were made in the data collection period. However, only 648 postings are related to apostasy. The data were classified according to the types of speech acts. Expressive speech act is the most frequent speech act (33\%, $\mathrm{n}=215)$, followed by the directive $(27 \%, \mathrm{n}=177)$, assertive $(22 \%, \mathrm{n}=141)$, and commissive $(18 \%, \mathrm{n}=115)$, respectively. Based on the speech acts used, it is discernible that the apostate attempts to engage other Facebook users and persuade them into accepting her ideology while gaining their support. This paper is novel in the sense that it puts forth the social actions of an apostate which is very scarce in literature. It is also methodologically innovative as it uses social media postings as a tool to explore the apostate's social actions in an online space.
\end{abstract}

Keywords: apostasy, apostate, Facebook, Malaysia, Islam, speech acts

\section{Introduction}

Social networking site (SNS) is the people's choice platform for communication purposes in this digital era (Boyd \& Ellison, 2008; Rashid et al., 2016). Among all, Facebook emerges as a stand out platform for people to communicate and interact with each other around the world. This study sought to examine the language used by an apostate on her Facebook Timeline through the speech act perspective. Apostasy is a very sensitive topic to talk about in this country-Malaysia. With Islam being the official religion of the country, apostasy is not something that can be accepted easily by the public (Mohamad et al., 2017). Islam has set a severe punishment for its followers who renounce the religion. Consequently, apostates are being oppressed and cast aside by the major society in this country. Before the emergence of internet, apostates have been living their lives in fear and discreet — keeping the apostasy just to themselves (Mohamad et al., 2017). However, the SNS has helped them to come out and bridge the gap by allowing them to voice out their feelings, ideas, and philosophy. Through speech act perspective, this study is hoped to provide insights into the strategic use of language by an apostate to communicate with other people through Facebook postings.

\section{Speech Acts}

Speech acts can be defined as collections of dialogue that bring meaning and provide reality. Searle (1970) describes speech act as a language action. Different kinds of speech acts, such as statements, commands, and questions, enable a person to start interacting not only to him/herself, but also to other people around him/her. Consequently, this situation influenced the behavior (attitudes and actions) of that particular person towards other persons of whom he/she communicates with (Cooren, 2005).

Speech acts analysis is not new to scholars and researchers. It has been the focus of research for many years. However, the use of speech acts on social media is still not widely explored especially in the context of an apostate. For instance, Overbey \& Preston-Matto (2002) explored the development of social interaction and characters from the television show, Buffy the Vampire Slayer, through speech acts perspective. Another 
example is the research conducted by Egner (2006) who studied the differences between Westerners and Africans cultures through "promising" speech acts from global perspectives. Previous studies on speech acts have a common objective, that is, to understand the social actions performed through language use.

Searle (1969) who is the proponent of speech acts theory proposes five types of speech acts: Assertive, commissive, declarative, directive, and expressive. Assertive speech act is an attempt by a person in stating the truth of the uttered statement (i.e., representatives, concluding), while commissive speech act indicates the commitment of a person to do something in the future (i.e., offering, promising, threatening). Declarative speech act is a declaration which can immediately change the state of the world (i.e., You are fired!). Directive speech act is a command attempted by a person to get the receiver to do something (i.e., requesting, commanding, questioning), whereas, expressive speech act is the expressions that represent the psychological state of a person (i.e., apologizing, thanking, welcoming, congratulating).

\subsection{Recent Research on Speech Acts on Social Media}

This sub-section reviews recent studies on speech acts on social networking sites (SNSs): Wulandari (2014) and Carr, Schrock, \& Dauterman (2012). This review provides a useful background to this study in terms of speech acts in the context of SNS.

Wulandari (2014) carried out a study to identify types and functions of speech acts on Facebook postings made by students of Muhammadiyah University of Surakarta, Indonesia. The students are English majors at the university. A total of 160 postings were analyzed and Wulandari found that Searle's (1969) five types of speech acts are integrated within the postings: Representative, directive, commissive, expressive, and declarative. Expressive speech act emerges as the most used speech act $(40 \%, \mathrm{n}=64)$, followed by representative $(33 \%, \mathrm{n}=53)$, directive $21 \%(21 \%, \mathrm{n}=34)$, commissive $(5 \%, \mathrm{n}=8)$ and declarative $(0.6 \%,=1)$ speech acts. In terms of function, the speech acts identified perform the following functions:

(1) Representative speech act has functions of describing, asserting, and informing

(2) Directive speech act has the functions of requesting, commanding, persuading, prohibiting, asking, and suggesting

(3) Commissive speech act has the functions of offering and promising

(4) Expressive speech act has the functions of expressing sorrow feeling, pleasure, congratulation, greeting, longing, apology, boring, confusing, disappointing, dislike, hoping, satisfying, scaring, supporting, thanking, tiredness, yearning, and anger

(5) Declarative speech act has the function of declaring serious changes in the students' lives

(Wulandari, 2014, p. 2)

Wulandari comes to a conclusion that there are 30 functions of speech acts involved in Facebook postings by the students of Muhammadiyah University of Surakarta.

Carr, Schrock, \& Dauterman (2012) conducted a study to explore the use of speech acts in Facebook postings for mass and interpersonal interactions. The participants are 46 students who major in a telecommunication survey course from a large public university in the Midwest United States. Data generation took place for two months (April-May 2008). A total of 204 postings were analyzed. Carr et al. found that expressive speech act is the most frequently used speech act by the students. The frequency of each type of speech act is identical to the study conducted by Wulandari (2014). The findings of these two studies contribute to our understanding that Facebook is mainly used for users to express themselves though it is also used to perform representative, commissive, directive and declarative acts.

\section{Methodology}

This study analyzed speech acts in the Facebook Status Updates posted by an apostate. Lily (pseudonym) is a solitary participant in this study. Lily is a female apostate who renounced Islam, born and bred in Malaysia. Upon getting the asylum status, she is now residing in the United State of America. She received many death threats from social media users after she publicly declared her renunciation.

Lily has given her consent to take part in this study. The observation of her Facebook Timeline took place for two years, from January 2015 up to December 2016. Throughout the two-year period, she posted more than 4000 posts on several issues related to her apostasy as well as her personal life. However, only 648 Facebook postings are related to apostasy. This paper deductively analyzes the speech acts in the postings by using Searle's (1969) typology of speech acts as analytic lens. 


\section{Analysis and Discussion}

The analysis of the postings reveals that only four types of speech acts are used by Lily: Expressive, directive, assertive, and commissive speech acts. There is no evidence for declarative speech act, which is the last type of speech act proposed by Searle (1969).

\subsection{Expressive Speech Act}

Expressive speech act is the most frequent speech act used by Lily $(33 \%, \mathrm{n}=215)$. This is not surprising as Facebook enables her to express her feelings, opinions, and emotions without having to meet the public face-to-face. After she publicly declared herself as an apostate, she receives several death threats and because of that she cannot simply express herself offline. Facebook serves as a safe platform for her to reach out to the public. Extract 1 shows how she despises religions and their followers using expressive speech act.

\section{Extract 1}

I hate people who look down on other people because of difference in religious beliefs. Fuck all of you.

\section{[Lily, FP44]}

Lily condemns the attitude of religious people who think that their religion is superior then the other religions. She uses bad word "fuck" to accentuate her hatred towards them. She seems to provide a justification for her renunciation of Islam that people should be given a freedom to choose their religious beliefs. By expressing the hatred, Lily conveys her message to the readers that they are doing a wrong thing for hating someone with a different religious belief.

Lily also express her sadness on Facebook. For her, extremists of a religion create problems to the world, as shown in Extract 2 below.

\section{Extract 2}

My friend, Chris (Pseudonym) once said, if you want to erase people's culture, identity, and history, you destroy their art and books...

I was sad when I see ISIS killing those innocent folks, but I cried when I see them destroy those ancient statues...

[Lily, FP45]

In this posting, she portrays herself as a peace lover who values art and humanity. She disapproves any kind of actions that promote violence especially killing people and destroying property, history, and culture. Her expressive postings are also inclined towards her personal favourites, such as foods, sceneries, and pets. However, most of the times, she constructs the postings to sarcastically comment on Islamic teaching. In Extract 3 for example, she expresses her happiness to let a dog licks her hand. In Islam, it is forbidden to touch a dog unless there is an urgent need to do so, such as for the purpose of rescuing it. Hence, this expression of happiness in this posting is done to make fun of Islamic teaching.

\section{Extract 3}

I let a dog lick my hand in the bus. I'm so happy.

[Lily, FP31]

\subsection{Directive Speech Act}

This is the second most frequent act performed through Lily's postings $(27 \%, \mathrm{n}=177)$ where she orders or requests her followers on Facebook to do something. Extract 4 below is an example of directive act where Lily requests readers to think of "true Islam" using rhetorical questions which she poses sarcastically.

Extract 4

Muslim moderates be like,

ISIS is not true Islam,

Taliban is not true Islam,

Saudi is not true Islam,

So, who's the true Islam? You? But you barely even read your Quran.

[Lily, FP20]

As can be seen in the extract above, Lily attempts to mock Islam by relating it to the terrorist groups - ISIS and Taliban. She also puts forth that Saudi is also not accepted by all Muslims as true Islam. This is ironic because 
Mecca and Medina which are the holy land in Islam are located in the Kingdom of Saudi Arabia. Mocking Islam and showing that there is no single version of "true Islam" can be seen as her attempt to encourage readers to question their belief.

Another example of directive speech act is shown in Extract 5. She indirectly requests readers to reevaluate their belief towards the concept of heaven in Islam. This is done by sarcastically commenting on what good Muslims will get when they go to heaven. For her, the good things promised in heaven are outdated and Islamic preaching needs to be updated.

\section{Extract 5}

So Islam teaches that for Muslims if they go to heaven, men get an angel/virgin, but women get their husbands back. Or if you believe this Malay preacher, women get gold bracelets and china set.

Like whaaaat that's not heaven, in my heaven I'd get latest electronic gadgets like new iPhones and latest MacBooks and fitbit and shopping spree in Victoria Secret. And my heaven will also be full of dogs and cats

This heaven story need serious updating.

[Lily, FP115]

\subsection{Assertive Speech Act}

Assertive is the third most frequent type of speech act observed in Lily's Facebook posting $(22 \%, n=141)$. Assertive speech act takes place when an author states a fact to get the viewer/reader to attend to the belief. Lily obviously has a lot of facts to share with her Facebook followers to justify her stance and support her argument. Extract 6 represents her posting on assertive speech act.

\section{Extract 6}

Linda Sarsour is a Palestinian American living in a country where freedom of religion is guaranteed, and where female genital mutilation is illegal. Ayaan Hirsi Ali lived in Somalia where little girls were told that if they didn't get circumcised, their clitoris will grow long and no men would want to marry them.

\section{[Lily, FP4001]}

The posting above can be seen as her attempt to convince readers that there is no justice for women who live in a Muslim country. They are obliged to get circumcised even if they do not want to do it or else they will be badly affected that they will remain single throughout their life. In other words, she is persuading readers to believe that there is no freedom in Islam and its followers need to obey all the preaching as they are threaten with negative effects if they refused to oblige.

Lesbian, gay, bisexual, and transsexual (LGBT) is a very popular topic among apostates for discussion. Lily happens to be one of them who frequently posts on her Facebook about LGBT. Extract 7 shows her posting on LGBT which represents assertive speech act.

\section{Extract 7}

The awkward moment when I defend LGBT from Islam, but LGBT attack me for criticizing Islam.

They are like chicken defending $K F C$,

Turkeys defending Thanksgiving,

Cows defending Eid Al-Adha (Hari Raya Korban).

The stupid is very strong with this one.

[Lily, FP10]

Lily tells readers that she is attacked by LGBT people for criticizing Islam. Lily expresses her disbelief towards such action as she is supportive of LGBT. As an ex-Muslim, she knows that Islam does not approve LGBT, and therefore she is in awe by the action of LGBT defending Islam. She provides three simple analogies to portray this kind of action. The analogies are straightforward and may very well help her Facebook followers in understanding the current situation, for those who are still confused. She ends her posting by condemning the LGBT showing her disappointment towards this minority group. "Stupid" might justify the LGBT action according to Lily and the analogies that she provides. In this posting, she conveys the message that we might not get the support even if we do something right, that is, she is not supported by some of the LGBT people even though she defends them. Ironically, there is no instance on her Timeline that she has been attacked by LGBT people. Thus this posting can be seen as her indirect way to persuade us to do things which we perceive as right 
even though it is not approved by others because we will never be able to make everyone around us happy.

Lily needs to be bold and firm in making statements or stating facts so that she could convince people to believe her. By doing so, she can indirectly obtain more supporters by spreading her ideologies. At the same time, being bold and firm could help scare away the haters and reduce the insults and threats towards her.

\subsection{Commissive Speech Act}

Commissive speech act states the commitment of an individual to do something in the future. This type of speech act is used by Lily for 115 times (18\%) in her posting throughout the data generation period. For instance, in Extract 8 below, she tells readers that she always wants to do the right thing even though it is not easy to do so. By projecting this good intention, Lily can be seen to construct the identity of a good person. She is telling the readers that she questions Islamic teaching for a good reason and she will keep questioning the teaching which she perceives as wrong even though people might hate her for doing so. It shows her determination to fight her crusade even though she is being oppressed by society and received death threats for her apostasy. This commissive speech act summarizes everything that she has ever fought for in her apostasy - action, ideology, expression, crusade, and decision

Extract 8

I want to always do the right thing, even when the right thing is a difficult thing to do.

[Lily, FP19]

Lily is firm and loud when it comes to topics such as terrorism, violence, and oppression. She is against all those elements, actions, and events that could cause disharmony. She will make sure that her voice is clearly heard and her intention is well acknowledged by many. Another example of commissive speech act with respect to this matter is shown in Extract 9 below.

Extract 9

Use words to express your dissatisfaction with the world-no matter how provocative, use words. Not by using bombs strapped to your body in suicide missions. This is the 21st century. Let's talk.

[Lily, FP23]

She encourages people to speak in order to express any discontent. Even for the worst kind of discontent, she wants people to express it with words, either written or verbally. By diplomatic discussion, the world might just become a better place and it could as well prevent extremism act from happening. She urges people who expresses their feeling through suicide mission to become more civilized by talking, in line with the development of the modern world. She stretches her posting until the end for her to state her commissive act by committing herself to use words and talks. The commitment that she undertakes will not be a problem for her provided that she already has the platform on Facebook.

\section{Conclusion}

Lily mainly posts on Facebook to express feelings, to request readers to do something, and to let readers know of her future actions and intentions. These are strategically done using expressive, directive, assertive and commissive speech acts. By expressing her feelings, she can be seen to gain sympathy from the readers thus obtaining their support. She constantly requests the readers to reevaluate their belief and do not blindly follow Islamic teaching. She also strategically uses the commissive speech act to share her future intentions and actions that she always wants to do the right thing in her life. In other words, she is telling readers that she has done the right thing by renouncing Islam as she perceives this religion as problematic.

Future studies should extend the scope of this study by analyzing the audiences' responses to the postings. Analysis of audiences' responses will provide better insights into the influence of the postings towards the public.

\section{Acknowledgement}

This paper is funded by the Malaysia Ministry of Higher Education under the Fundamental Research Grant Scheme no FRGS/1/2016/SSI03/UniSZA/02/5.

\section{References}

Baron, N. S., Squires, L., Tench, S., \& Thompson, M. (2005). Tethered or mobile? Use of away messages in instant messaging by American college students. London, England: Springer-Verlag. https://doi.org/10.1007/1-84628-248-9_20 
Boyd, D. M., \& Ellison, N. B. (2008). Social network sites: Definition, history, and scholarship. Journal of Computer-Mediated Communication, 13(1), 210-230. https://doi.org/10.1111/j.1083-6101.2007.00393.x

Carr, C. T., Schrock, D. B., \& Dauterman, P. (2012). Speech acts within Facebook status messages. Journal of Language and Social Psychology, 31(2), 176-196. https://doi.org/10.1177/0261927X12438535

Cooren, F. (2005). The contribution of speech act theory to the analysis of conversation: How presequences work. Mahwah, NJ: Lawrence Erlbaum.

Egner, I. (2006). Intercultural aspects of the speech act of promising: Western and African practices. Intercultural Pragmatics, 3(4), 443-464. https://doi.org/10.1515/IP.2006.027

Mohamad, A., Rashid, R. A., Yunus, K., Abdul Rahman, S. B., Darus, S., Musa, R., \& Mat Teh, K. S. (2017). A review of apostasy cases in Malaysia. Man in India, 97(16), 297-301.

Mohamad, A., Rashid, R. A., Yunus, K., Abdul Rahman, S. B., Darus, S., Musa, R., \& Mat Teh, K. S. (2017). Discourse analysis on newspaper reports of apostasy cases. Journal for the Study of Religions and Ideologies, 16(48), 96-111.

Overbey, K. E., \& Preston-Matto, L. (2002). Staking in tongues: Speech act as weapon in Buffy. Lanham, MA: Rowman \& Littlefield.

Rashid, R. A., Yahaya, M. F., Rahman, M. F., \& Yunus, K. (2016). Teachers' informal learning via social networking technology. International Journal of Emerging Technologies in Learning, 11(10), 76-79. https://doi.org/10.3991/ijet.v11i10.5908

Searle, J. R. (1969). Speech acts. Cambridge, England: Cambridge University Press. https://doi.org/10.1017/CBO9781139173438

Searle, J. R. (1970). Speech acts: An essay in the philosophy of language. Cambridge, England: Cambridge University Press.

Wulandari, S. (2014). Speech act analysis on Facebook statuses used by students of Muhammadiyah University of Surakarta (Unpublished degree article). School of Teacher Training and Education, Muhammadiyah University of Surakarta.

\section{Copyrights}

Copyright for this article is retained by the author(s), with first publication rights granted to the journal.

This is an open-access article distributed under the terms and conditions of the Creative Commons Attribution license (http://creativecommons.org/licenses/by/4.0/). 